\title{
Research on the Current Situation, Difficulties and Solution of Financing Situation in Shanghai Private Technology Enterprises
}

\author{
Zhengrong Xiao \\ School of Management, East China University of \\ Science and Technogy \\ Shanghai, China \\ E-mail: shara318@126.com
}

\author{
Hongtao Yang \\ School of Management, East China University of \\ Science and Technogy \\ Shanghai, China \\ E-mail: yanght@ecust.edu.cn
}

\begin{abstract}
With the rapid development, Shanghai private technology enterprises' competition is more and more complicated and they face a lot of problems especially for financing which needs to be further researched and solved. However, until now, there has been lack of research analyzed by questionnaire on financing problems about Shanghai private technology enterprises. This paper used questionnaire survey data from 248 private technology enterprises in Shanghai to describe their current situation of financing and effectively analyzed the financing difficulties. Finally, on the basis of the current situation and difficulties, researchers proposed our solution in order to provide some guidance and reference for the further development of Shanghai private technology enterprises.
\end{abstract}

Keywords- Private Technology Enterprises; Difficulties; Solution; Financing; Current Situation

\section{INTRODUCTION}

Due to high level of technology innovation capability and flexible operational mechanism, private technology enterprisers help to promote Chinese economic growth, and increase employment opportunities and improve regional innovation ability. They have gradually expanded from manufacturing, retail trade and social services to the field of high technology, including modern electronics, fine chemicals, new energy, energy saving, environmental protection and biological medicine. Moreover, the proportion of private enterprises in new high-tech enterprises increases continually so that they have played an important role in "science and education encouraging city". However, with the rapid development, private technology enterprises' competition is more and more complicated and they face a lot of problems. Especially, enterprisers' financing is a significant and difficult one, which needs to be further researched and solved.

Studies of private technology enterprises' financing focus on two aspects: (1) why the problem of the private technology enterprises' financing happens and how to deal with it; (2) what the capital demand of private technology enterprises is and where the capital comes from under the different life cycle. Gu iquan Hong (2004) argued that the difficulty of private technology enterprises' financing had three aspects:(1) bank had limited effect on private technology enterprises' financing; (2) capital market could not solve the difficulty of private technology enterprises' financing; (3) The government could not solve the problem of private technology enterprises' financing. Only a few enterprises could get support from the government. Meanwhile, the perfect social credit system was helpful to fundamentally solve the problem of enterprises' financing ${ }^{[1]}$. Hongyu Dai (2007) considered that there were two reasons for the difficulty of private technology enterprises' financing, including internal cause and external cause. Lacking credit of enterprises' financing and abnormal financial management was the internal cause. The high access level of direct financing market, including stocks and bonds, was external cause ${ }^{[2]}$. Tuoyuan Fan (2007) argued that the reasons for the difficulty of private technology enterprises' financing were as follows: unreasonable financial structure, myopia behavior in risk investment, immature capital market and suppressed folk financing. What's more, relevant countermeasures are proposed to solve these problems ${ }^{[3]}$. Yongzhou Li (2006) argued that the difficulty of private technology enterprises' financing had two main reasons: (1) the development of enterprise and strategic alliance lagged behind; (2) The private technology enterprises were difficult to use commercial credit ${ }^{[4]}$. Therefore, he thought that countries should set up a financial mutual aid agency and develop the commercial credit between enterprises.

However, until now, there is little research on financing problems about Shanghai private technology enterprises through questionnaire. Therefore, researchers should make up the shortage.

\section{RESEARCH METHOD}

Questionnaire survey is adopted in this research. More than 300 private technology enterprises in Shanghai serve as respondent. They are randomly selected by the Shanghai technology enterprises confederation. The main objects of the questionnaire are senior management personnel in each enterprise. Researchers recovered 328 questionnaires totally. After careful review, the invalid questionnaires which the options answer is not complete or selection factors are in full accord were eliminated. Finally, 248 valid questionnaires were recovered from 300 enterprises and the effective rate was $75.6 \%$. In addition, private technology enterprises in different age, size and industry are included in the sample companies, so it has good representation. 


\section{DESCRIPTION OF CURRENT FINANCING SITUATION}

The growth of the private technology enterprise depends on the financing. However, in the process of development, financing is the major problem for most private technology enterprises ${ }^{[5-6]}$. According to the questionnaire of Shanghai private technology enterprise, researchers find that financing situation of Shanghai private technology enterprises present the following features:

(1) More than half of the private technology enterprises have the demand of financing. Most of them can meet their financing demand. However, many small enterpris es still can't meet their financing demand.

Among the 248 enterprises which were surveyed, 140 of them accounts for $56.5 \%$ of the total samples have the demand of financing. Among the 140 enterprises, 23 of them accounts for $9.3 \%$ have huge funding gap. Only 108 enterprises accounts for $43.5 \%$ have no financing demand.

In addition, it can be seen from Table 1 in the 248 sample enterprises, 56 of them accounts for $22.6 \%$ can rarely meet their financing demand. 192 of the m accounts for $77.4 \%$ can meet their financing demand which contain 8 enterprises whose financing demand are fully met (accounting for $3.2 \%$ ) , 101 enterprises whose financing demand are basically met (accounting for 40.7\%) and 83 enterprises whose financing demand are partly met (accounting for 33.5\%). Among the 56 enterprises whose financing demand are rarely met, 54 of the $m$ have less than 100 employees , 2 of them have employees between 100 and 200, and none of them have more than 200 emp loyees. This suggests that the financing demand of most enterprises can be met at different degrees and smaller enterprises can hardly meet their financing demand.

TABLE I. CROSS-OVER ANALYSIS OF THE ENTERPRISE SCALE AND DEGREE OF FINANCING TO MEET DEMAND ( $\mathrm{N}=248)$.

\begin{tabular}{|c|c|c|c|c|c|c|}
\hline \multirow{2}{*}{\multicolumn{2}{|c|}{ Indicator }} & \multicolumn{4}{|c|}{ Degree of financing to meet demand } & \multirow[b]{2}{*}{ Total } \\
\hline & & $\begin{array}{l}\text { Fully } \\
\text { meet }\end{array}$ & $\begin{array}{c}\text { Basically } \\
\text { meet }\end{array}$ & $\begin{array}{c}\text { Partly } \\
\text { meet }\end{array}$ & $\begin{array}{c}\text { Rarely } \\
\text { meet }\end{array}$ & \\
\hline \multirow{4}{*}{$\begin{array}{l}\text { Number } \\
\text { of the } \\
\text { employ } \\
\text { ees }\end{array}$} & $<100$ & $\begin{array}{l}1 \\
0.7 \%\end{array}$ & $\begin{array}{l}21 \\
14.7 \%\end{array}$ & \begin{tabular}{|l|}
67 \\
$46.9 \%$
\end{tabular} & $\begin{array}{l}54 \\
37.8 \%\end{array}$ & $\begin{array}{l}143 \\
100.0^{c}\end{array}$ \\
\hline & $\begin{array}{l}100- \\
200\end{array}$ & $\begin{array}{l}1 \\
2.5 \%\end{array}$ & $\begin{array}{l}33 \\
82.5 \%\end{array}$ & $\begin{array}{l}4 \\
10.0 \%\end{array}$ & $\begin{array}{l}2 \\
5.0 \%\end{array}$ & $\begin{array}{l}40 \\
100.0\end{array}$ \\
\hline & $\begin{array}{l}201- \\
500\end{array}$ & $\begin{array}{l}1 \\
2.0 \%\end{array}$ & $\begin{array}{l}42 \\
84.0 \%\end{array}$ & $\begin{array}{l}7 \\
14.0 \%\end{array}$ & \begin{tabular}{|l|}
0 \\
$0.0 \%$
\end{tabular} & $\begin{array}{l}50 \\
100.0\end{array}$ \\
\hline & $>500$ & $\begin{array}{l}5 \\
33.3 \%\end{array}$ & \begin{tabular}{|l|}
5 \\
$33.3 \%$
\end{tabular} & \begin{tabular}{|l|}
5 \\
$33.3 \%$ \\
\end{tabular} & \begin{tabular}{|l|}
0 \\
$0.0 \%$
\end{tabular} & $\begin{array}{l}15 \\
100.0 c\end{array}$ \\
\hline \multicolumn{2}{|l|}{ Total } & $\begin{array}{l}8 \\
3.2 \% \\
\end{array}$ & $\begin{array}{l}101 \\
40.7 \%\end{array}$ & \begin{tabular}{|l|}
83 \\
$33.5 \%$
\end{tabular} & $\begin{array}{l}56 \\
22.6 \%\end{array}$ & $\begin{array}{l}248 \\
100.0\end{array}$ \\
\hline
\end{tabular}

(2) For majority of private enterprises own funds and bank loans are the main financing channels.

For financing channels for enterprises from the sample point of view, its own funds are followed by a bank loan. $60 \%$ of enterprises financed by its own funds, an absolute majority; $34 \%$ of companies have chosen to bank loans as financing; $3 \%$ of companies have chosen to internal financing; $2 \%$ of companies have chosen to microfinance company; only $1 \%$ of the enterprise Select the private lending.

Researchers can conclude from the sample enterprises that own funds are their first choose for financing and then bank loan are second choose of financing channel. Most of them use their own funds for financing (accounting for $60 \%$ ); and $34 \%$ of them choose bank loan as financing channel; and only $2 \%$ choose microfinance company as financing channel; what is more, only $1 \%$ of the enterprises select the private lending.

(3) In totally, the financing environment of Shanghai private technology enterprises should be improved. Compared with the small enterprises the satisfaction degree of financing environment for large or medium private technology enterprises is higher.

In the sample of 248 enterprises, 101 enterprises show their satisfaction for the financing environment of Shanghai (accounting for 40.7\%). 46 enterprises point out that the financing environment is ordinary (accounting for 18.5\%). 101 enterprises are not so satisfied with the financing environment (accounting for 40.7\%). And none of them are very dissatisfied with the financing environment. This suggests that, overall, the financing environment of Shanghai private technology enterprises needs further improvement.

Researchers can conclude that only $14.7 \%$ of these enterprises whose number of employees is less than 100 are satisfied or very satisfied with the financing environment of Shanghai and $70.6 \%$ of them are not so satisfied according to the cross-over analys is of enterprise scale and the financing environment of Shanghai (details seen in Table 2). Compared with these small enterprises, researchers can see that $77.5 \%$ of the $m$ whose number of employees is between 100 and 200 are satisfied or very satis fied with the financing environment of Shanghai, $76 \%$ of them whose number of employees is between 201 and 500 are satisfied or very satisfied and $72.7 \%$ of them whose number of emp loyees is more than 500 are satisfied or very satisfied. In general, the satisfaction degree of financing environment for large or medium private technology enterprises is higher, which is accordance with the result of enterprises' financing demand.

TABLE II. CROSS-OVER ANALYSIS OF THE ENTERPRISE SCALE AND DEGREE OF SHANGHAI FINANCING ENVIRONMENT TO MEET DEMAND $(\mathrm{N}=248)$.

\begin{tabular}{|c|c|c|c|c|c|c|c|}
\hline \multirow{2}{*}{\multicolumn{2}{|c|}{ Indicator }} & \multicolumn{5}{|c|}{$\begin{array}{l}\text { Degree of Shanghai financing environment to } \\
\text { meet demand }\end{array}$} & \multirow{2}{*}{ Total } \\
\hline & & \begin{tabular}{|l|} 
Very \\
satisfied
\end{tabular} & Satisfied & \begin{tabular}{|l|} 
Average \\
satisfied
\end{tabular} & $\begin{array}{l}\text { Not so } \\
\text { satisfied }\end{array}$ & \begin{tabular}{|l|} 
Very \\
dissatisfied
\end{tabular} & \\
\hline \multirow{4}{*}{$\begin{array}{l}\text { Num- } \\
\text { ber of } \\
\text { the } \\
\text { emplo } \\
\text { yees }\end{array}$} & $<100$ & $\begin{array}{l}6 \\
4.2 \% \\
\end{array}$ & $\begin{array}{ll}15 \\
10.5 \% \\
\end{array}$ & \begin{tabular}{|l|}
11 \\
$14.7 \%$ \\
\end{tabular} & $\begin{array}{l}101 \\
70.6 \% \\
\end{array}$ & \begin{tabular}{|l|l|}
0 \\
$0.0 \%$ \\
\end{tabular} & $\begin{array}{l}143 \\
100.0 \%\end{array}$ \\
\hline & $\begin{array}{l}100- \\
200\end{array}$ & $\begin{array}{ll}15 \\
37.5 \%\end{array}$ & $\begin{array}{l}16 \\
40.0 \%\end{array}$ & $\begin{array}{l}9 \\
22.5 \%\end{array}$ & $\begin{array}{l}0 \\
0.0 \%\end{array}$ & $\begin{array}{l}0 \\
0.0 \%\end{array}$ & $\begin{array}{l}40 \\
100.0 \%\end{array}$ \\
\hline & $\begin{array}{l}201- \\
500\end{array}$ & \begin{tabular}{|l|}
11 \\
$22.0 \%$
\end{tabular} & $\begin{array}{l}27 \\
54.0 \%\end{array}$ & $\begin{array}{l}12 \\
24.0 \%\end{array}$ & $\begin{array}{l}0 \\
0.0 \%\end{array}$ & $\begin{array}{ll}0 \\
0.0 \%\end{array}$ & $\begin{array}{l}50 \\
100.0 \%\end{array}$ \\
\hline & $>500$ & $\begin{array}{l}1 \\
6.7 \% \\
\end{array}$ & $\begin{array}{l}10 \\
66.7 \% \\
\end{array}$ & $\begin{array}{l}4 \\
26.7 \% \\
\end{array}$ & $\begin{array}{l}0 \\
0.0 \% \\
\end{array}$ & $\begin{array}{ll}0 \\
0.0 \% \\
\end{array}$ & \begin{tabular}{|l|l|}
15 \\
$100.0 \%$ \\
\end{tabular} \\
\hline \multicolumn{2}{|l|}{ Total } & $\begin{array}{l}33 \\
13.3 \% \\
\end{array}$ & $\begin{array}{l}68 \\
27.4 \% \\
\end{array}$ & $\begin{array}{l}46 \\
18.5 \% \\
\end{array}$ & $\begin{array}{l}101 \\
40.7 \% \\
\end{array}$ & $\begin{array}{l}0 \\
0.0 \%\end{array}$ & \begin{tabular}{|l|}
248 \\
$100.0 \%$ \\
\end{tabular} \\
\hline
\end{tabular}

\section{ANALYSIS OF FINANCING DIFFICULTIES}

The development of private technology enterprises depend on the support of funds, however, insufficient funds and difficult financing are the main problems in the process of development of Chinese private technology enterprises ${ }^{[6-7]}$. Due to the uncertain technology innovation and lagging earnings, the risk of private technology 
enterprises has increased. Also, it led to the enterprise face difficulties in financing. Through the analysis of survey data, researchers think the problems of Shanghai private technology enterprises' financing are as follows:

(1) The proportion of endogenous financing is large in the capital structure.

Through the survey of Shanghai private technology enterprises' financing researchers find that many enterprises use its own funds as the main financing channels and these enterprises occupy a large proportion. This shows that Shanghai private technology enterprises rely too much on its capital financing channel. This kind of financing structure will affect the long-term development of the private technology enterprises: first, when the enterprises develop to a certain size, internal financing can't meet the increasing demand of financing; second, the endogenous financing is not conducive to finance norm, moreover, researchers will lose many external financing opportunities.

(2) The financing environment is bad for the development of small private technology enterprises.

In this survey, the small enterprises whose employees are under 100 account for $57.7 \%$. They are the main force of private technology enterprises. However, in our investigation, researchers find that in small enterprises, $70.6 \%$ of enterprises are not very satisfied with financing environment of Shanghai and large and medium enterprises are satisfied with the financing environment of Shanghai; Only $49 \%$ of small enterprises can independently choose financial institutions and above $80 \%$ of large and medium enterprises can independently choose financial institutions; $37.8 \%$ financing demand of small enterprises is rarely met, however, only $5 \%$ of financing demand of enterprises which have 100-200 employees is rarely met. As to enterprises of other scale, on financing demand is rarely met. Throughout these data, researchers can find that, in terms of the financing environment in Shanghai, it is not favorable to the development of small private technology enterprises.

(3)The procedure of bank loan is tedious, while the loan interest rate and other cost are too high.

Due to high risk, less mortgage assets and urgent demand of small and medium-sized technology enterprises' financing, risk investment and direct financing will not be able to effectively meet the demand of enterprises for capital. According to the survey of Shanghai private technology enterprises financing channels, bank loan is still the main channel for small and medium-sized technology enterprises' financing in our country now.

First, the procedure of mortgage loan is complicated and the fee is high. For example, in the procedure of evaluation of land mortgage and registration, evaluation contains application, field survey, present price estimation, etc.; registration contains survey of the right of land use, cadastral surveying and mapping, encumbrance of landed estate registration, etc. After finishing the relevant registration in the housing department, the enterprises can deal with certificate of other rights. Therefore, the above process need to spend a lot of time and energy, also the cost of mortgage and evaluation is high. Because of these tedious programs of loan, it is difficult for bank loan to meet the urgent demand of private technology enterprises for capital. Some business will lose business opportunities because of the long time for loan approval.

Second, because the private technology enterprises have the characteristics of high investment, high-growth and high returns, the main investments of enterprise are intelligence and other intangible assets, so the fixed assets are relatively lacking. The present situation inevitably conflicts with the asset protection mechanism of commercial bank loan. Even if the private technology enterprises develop successfully and the enterprise is profitable, it also has nothing to do with the bank. The bank can only recover the loan principal of the loan and they don't have the right to share high yield. However, once the enterprises failed, banks will suffer serious loss. Because the private technology enterprises don't have many fixed assets to compensate. In this case, the bank only undertakes high risk of the enterprise, but did not enjoy the high yield of the enterprise. Asymmetry of the risks and benefits reduces enthusiasm of bank loan for private technology enterprises.

\section{SOLUTION OF FINANCING SituAtion}

Endogenous financing is the major financing channel of private technology enterprises. Moreover, the financing demand of start-ups and small and medium-sized enterprise is difficult to satisfy. This situation is consistent with our survey. The study shows that most of Shanghai private technology enterprises create money mainly by the founder. Only a few enterprises can get bank loan in development. Many enterprises are difficult to loan from bank, especially for small and medium-sized enterprise. Thus, the main financing way of Shanghai private technology enterprises endogenous financing. Exogenous financing only occupies less proportion. The single financing channel results in the difficulty of private technology enterpris es' financing ${ }^{[8-10]}$.

Actually, the state has set up a technical innovation fund for small and medium-sized technology enterprises in order to solve the problems of the financing. Discount loans, free sponsorship, capital investment and many other ways are used to support and guide technology innovation activities of the small and medium-sized enterprises. The state has issued some policies and measures for small and medium-sized enterprises' financing, also many commercial banks have introduced a number of financial products for small and medium-sized enterprises. In addition, Shanghai implemented "developing project about the listing of small and medium-sized enterprise ". The government encourages the small and medium-sized enterprises to finance in the domestic and foreign securities market through the restructuring listed. Thus, the main problem of private technology enterprises' financing is not the financing policy and limited financial instrument. Lack of docking mechanism between the private technology enterprises and financial institutions is the key.

In conclusion, researchers think researchers need to improve the difficulty of private technology enterprises' financing in the following aspects:

(1) Efforts should be made to provide platform for private technology enterprises and financial institutions to exchange and cooperate. After enhancing the understanding between each other, the financial institutions will realize the potential of private technology 
enterprises and strengthen the credit aid for private technology enterprises ${ }^{[11]}$.

(2) Further speed up the development of local technology bank. The products of private technology enterprises have high technology. Once the research successes, it will generate high external benefit. Even it can benefit the whole society. Therefore, developing the technology bankcan achieve win-win situation.

\section{ACKNOWLEDGEMENTS}

This work is financially supported by many scholars who work for Shanghai Science and Technology Commission and Shanghai private technology enterprises. They give us a lot of valuable advice, relevant information and data.

\section{REFERENCES}

[1] Quanhong Gui, Yuanrui Zhan. Difficult Financing Position of Private Scientific and Technological Enterprises and Its Way Out [J]. EnterpriseEconomy. Vol.8(2004): pp.134-135.

[2] Hongyu Dai. Difficult Financing Position of Private Scientific and Technological Enterprises and Its Way Out [J]. Anhui Agricultural machinery. Vol.2(2007): pp. $8-12$

[3] Tuoyuan Fan \& Xi Hong. Research on Financing Channels of Private Technology Enterprises [J]. Science-Technology and Management. Vol.6 (2007): pp.63-67.
[4] Yongzhou Li. Obstacles and Innovation of Private Technology Enterprises' Financing Channels [J]. Forum on Science and Technology in China. Vol.3(2006): pp.22-26.

[5] Cui X G. Research on Financing Demand and Capital Structure Choice of SMEs in China An Empirical Test on Small and Medium-sized Listed Companies[J]. Journal of Beijing T echnology \& Business University, 2008 .

[6] Yang L, Qiu E N. Analysis of financing demand and methods for middle-size and small-size high technology enterprise in growth age[J]. Science-Technology and Management, 2009.

[7] TANG Wen,CHEN Aizu1,RAO Qian; Solving the Financing Plight of High-tech Small and Medium Enterprises by Innovating in Technology and Financial Cooperation[J];Science and Technology Management Research;2011-07

[8] Wei S, Li H. How Does Government Subsidies Influence the External Financing of Listed Companies[J]. Journal of Northwest University, 2014.

[9] Chen J B, Zhang Z Q, Lai M S, et al. Research on financing strategy of scientific and technological small and medium enterprises based on life cycle: a case of Liaoning Province[J]. Journal of Shenyang University of Technology, 2014.

[10] Ding T. Analysis on the Financing Mode of Intellectual Property Impawn for Chinese Medium and Small-sized Sci-Tech Enterprises-Taking Science and Technology Bank as an Example[J]. Journal of Jinling Institute of Technology, 2014.

[11] Meng Huazhen. Financing Services to Be Improved[J]. China International Business. Vol.6(2014): pp.29-29. 